\title{
Hepatitis B Viral Load PCR Measurement
}

National Cancer Institute

\section{Source}

National Cancer Institute. Hepatitis B Viral Load PCR Measurement. NCI Thesaurus.

Code $C 74725$.

The determination of the hepatitis B viral load in a sample using polymerase chain reaction. 